\author{
Andrii Kobetiak, \\ Candidate of Philosophical Sciences, \\ Associate Professor of the Department of Economic Security, \\ Public Administration and Management \\ (Zhytomyr Polytechnic State University, Zhytomyr, Ukraine) \\ ORCID: 0000-0002-0457-922X \\ akobetyak2019@gmail.com
}

\title{
THE PROBLEM OF CANONICAL SETTLEMENT OF CHURCH-ADMINISTRATIVE DISUNITY OF THE ORTHODOX DIASPORA
}

The phenomenon of the Orthodox diaspora arises as a result of the powerful migration of the population in the late 19th-early 20th centuries. The carriers of the Orthodox faith did not want to assimilate among infidels. Religion, culture and language have played a powerful role in the selfidentification of immigrants. Each of the Local Churches, considering it their duty to guardianship the believers, even if they emigrated to non-Orthodox countries, have been establishing parishes in

Western Europe, North and South America. The expansion of the diaspora has led to the appearance of a unique ecclesiological model in the church system, when the bishops of different Local Churches operate simultaneously in the same territory. This directly contradicts a number of canons and the very tradition of the Orthodox Church.

The lack of regulation of the church administration of the diaspora gave rise to problems in the subordination of these churches. This system does not correspond to the traditions of the church,

but it was justified by the needs of the time and the special historical conditions caused by

migration of the population. One of the most important factors hindering the solution of the diaspora problem is financial dependence on parishioners from rich countries of Western Europe and America.

Representatives of Local Churches demonstrate radically opposite approaches to the problem of resolving the canonical settlement of the administrative fragmentation of churches in the diaspora. Most of the hierarchs defend their own right to the spiritual care of their fellow citizens in exile. On the other hand, the ideas and interests of the emigrants themselves are twofold. Some of them seek

to maintain cultural and religious ties with the Homeland, including through a single church. However, such church formations on the "new land" do not always have a recognized canonical status. Others fall within the jurisdiction of the Local Churches, which are generally recognized, mainly in the jurisdiction of Constantinople. The Ecumenical Patriarchate today makes major claims to the sole custody of the Orthodox diaspora, relying on the canons that give him primacy in the missionary work on the "barbarian lands".

The Great All-Orthodox Council which took place in Crete in 2016, did not provide a clear answer to the question of the jurisdiction of the Orthodox diaspora. Despite the accepted document

"Orthodox Diaspora", the diaspora issue remains relevant, as it directly violates a number of canons, the main one is the presence of several hierarchs with the same titles in the same territory.

Keywords: parallel jurisdictions, church, autocephaly, orthodox diaspora, canon law, patriarch, parish, metropolitan.

\section{Andrii Kobetiak. Problem kanonicznej osady oddziału kościoto-administracyjnego ortodoksyjnej diaspora}

W artykule analizuje się problemy kształtowania się i zatwierdzania ustroju administracyjnego ukraińskich Kościołów prawosławnych $w$ diasporze. Udowodniono, że Kościót prawosławny stat się ważnym czynnikiem dla zjednoczenia ukraińskiej diaspory, zachowania ich tożsamości kulturowej $i$ narodowej. Dla prawosławnych Ukraińców $w$ diasporze jedna z ważnych kwestii była potrzeba utworzenia struktury kościelnej. Poszerzenie diaspory spowodowało powstanie nowego modelu eklezjologicznego w ustroju Kościoła, który był uzasadniony potrzebami czasu $i$ 
szczególnymi warunkami historycznymi. On przewiduje działalność kilku biskupów różnych Kościołów partykularnych, co jest sprzeczne z wieloma kanonami i samą tradycja Kościoła prawosławnego. Przedstawiciele Kościołów partykularnych wykazuja radykalnie przeciwne podejścia do problemu rozwiąania kanonicznego rozstrzygnięcia rozdrobnienia administracyjnego kościołów w diasporze. Większość hierarchów broni własnego prawa do duchowej opieki swoich współobywateli na emigracji. Inni - należa do jurysdykcji Kościołów partykularnych, które sa powszechnie uznawane, głównie w jurysdykcji Konstantynopola.

Stowa kluczowe: jurysdykcje równoległe, kościót, autokefalia, diaspora prawosławna, prawo kanoniczne, patriarcha, parafia, metropolita.

\section{Андрій Кобетяк. Проблема канонічного врегулювання церковно-адміністративного поділу православної діаспори}

У статті аналізується проблеми становлення та утвердження адміністративного устрою украӥнських православних иерков у діаспорі. Доведено, щзо православна церква стала важливим фактором для гуртування украӥнської діаспори, збереження їх культурної й національної ідентичності. Для православних українців у діаспорі одним з важливих питань була необхідність формування церковної структури. Розширення діаспори зумовило виникнення нової еклезіологічної моделі в церковному устрої, яка була обтрунтована потребами часу та особливими історичними умовами. Вона передбачає діяльність декількох

єпископів різних помісних церков, щуо суперечить низиі канонів та самій традиціі

православної иеркви. Представники помісних церков демонструють кардинально протилежні підходи до проблеми вирімення канонічного врегулювання адміністративної роздробленості иерков у діаспорі. Більшість ієрархів відстоюють власне право на духовну опіку своїх співгромадян у еміграції. Інші - входять до юрисдикцій помісних иерков, які $\epsilon$ загальновизнаними, переважно в юрисдикиї Константинополя.

Ключові слова: паралельні юрисдикиії, иерква, автокефалія, православна діаспора, канонічне право, патріарх, парафія, митрополит.

Formulation of the problem. The study of the Orthodox diaspora in the 20th century indicates the search for ways to regulate church life outside the traditional spread of the Orthodox faith. The problem of the canonical regulation of the structure of the Orthodox Church outside the "canonical territory" has always been at the center of philosophical discourse, since it dates back to the time of the Ecumenical Councils. However, it acquires particular relevance at the beginning of the 20th century due to the active migration of the population, that led to the mass formation of new ethnoreligious formations. The absence of specific rules for spiritual care over non-Orthodox countries and the diaspora led to disputes among the Local Churches. Each of them defended their own right to patronage of emigrants from Homeland. This led to jurisdictional chaos, which was embodied in the existence of several "parallel jurisdictions" within the same country, and even within the same city. In addition, since the only legitimate jurisdiction was often absent, this led to the emergence of a significant number of religious organizations within a single national church.

Due to the significant growth of the network of parishes in the "scattering", because of the migration of the population at the end of the 19th and the beginning of the 20th century, a new phenomenon of the Orthodox diaspora appeared for the Universal Orthodoxy. The decrees of the Ecumenical Councils draw attention to the "land of the barbarians" and the need for spiritual guardianship over the believers living in those lands. In the heyday of Christianity and Byzantium, the question arose about spiritual missionary work to the "unenlightened" lands. In fact, every Christian is prompted to do so by the Christ's command "Go you therefore, and teach all nations, baptizing them in the name of the Father, and of the Son, and of the Holy Spirit:" (Matt. 28:19). Therefore, each of the Local Churches considered it their duty to preach to their neighborsinfidels. The prerogative of spiritual guardianship over the "lands of the barbarians" was given to the capital's Constantinople chair, which had special political influence in the empire. It is worth noting that in the Middle Ages there was no such active growth of Orthodox scattering and the compact residence of Orthodox Christians in countries with a dominant population of other 
religions. In the 20th century the church was not ready to theologically substantiate the phenomenon of the diaspora. There are no direct instructions and resolutions of the Ecumenical Councils that would regulate the issues of church-administrative structure of the diaspora.

The purpose of the article is a complex philosophical and religious study of the problem of canonical and legal regulation of the jurisdiction of churches of the modern Orthodox diaspora in the context of the formation of a single autocephalous principle of governing the Ecumenical Church.

Presenting main material. In Ukrainian and foreign historiography there are a number of studies devoted to the main problems of the formation of churches in the Orthodox diaspora. The analysis of the literature on this problem allows us to conditionally classify it into two groups: historically-religious, that is, scientific, and denomination ones.

The first group of literature includes monographs, analytical articles by Ukrainian and foreign historians and theologians, in which the issues of formation of the church system of the Orthodox diaspora are covered from the standpoint of academic religious studies and historical science. The first block of literature is represented by a small number of studies, as the question of the subordination of the churches of the Orthodox diaspora did not attract much attention from secular authors. Scholars were interested in it only in terms of canonical agreement of the current situation with the norms of ancient canons. However, a significant contribution of the scientific works of this series is the description of the general history of the development of the Orthodox Church and its individual parts, as well as statistic data.

In the context of the formation of the Ecumenical Church and its current state, the famous Ukrainian researcher O. Sagan pays special attention to the issue of jurisdictional development of the Orthodox diaspora. The monograph "Ecumenical Orthodoxy: essence, history, current state" is one of the most successful on the problems of the modern church in general. It pays special attention to the unregulated status of the Orthodox "scattering" as one of the important issues of the Ecumenical Church in the XXI century. Part of the monograph is devoted to a separate study of the phenomenon of ethno-denomination syncretism, which is one of the explanations for the emergence of a large number of independent institutions of the Orthodox diaspora.

For example, it is worth mentioning the work of M. Stokoe and L. Kishkovsky "Orthodox Christians in North America", which reveals in detail the formation of emigrant ethno-confessional formations in the history of the Orthodox churches of America. A separate section of one of the most successful denominational studies "The Orthodox Church", written by the famous theologian of the 20th century, Metropolitan Kallistos (Ware), is devoted to the formation of the Orthodox diaspora and its jurisdiction.

Much of the research is devoted to a detailed examination of separate jurisdictions abroad. In particular, the works of P. Bozhyk, I. Vlasovsky, R. Yerenyuk, T. Minenko, Y. Mulyk-Lutsyk, N. Plichkovsky, S. Savchuk, and P. Yuzyk are valuable in the study of the history of the Ukrainian church diaspora. A series of articles by the modern Ukrainian researcher I. Verstyuk is an attempt to systematize the main events in the development of the Orthodox diaspora.

A review of the literature shows that the issues of the historical development and canonicaladministrative settlement of the churches of the Orthodox diaspora were of interest to many foreign and domestic researchers. However, when covering problems in the activities of representatives of various Local Churches, many authors demonstrate a pronounced confessional approach. Most pay attention to the problem of the historical formation of the diaspora, and not to the search for ways to canonically arrange the diaspora into a unified organization. Therefore, there is a need for a deeper objective study that could present materials on the history of the formation of the "scattering" churches from the academic religious studies point of view.

For the first time, the issue of resolving the situation of the Orthodox diaspora was raised by active representatives of the churches of North America. The need to rethink approaches to the formation of the church structure of emigrant communities began to be realized in the 1920s and 1930s. One of the catalysts of the movement towards the consolidation of Orthodoxy in North 
America was that the flock consisted not only of emigrants, but also of representatives of the new generation born in North America. Gradually, the indigenous autochthonous population was added to the emigrants. Most of this new generation considered the USA or Canada as their homeland. That is why the development of a new policy of relations between Orthodox churches has become an obvious necessity.

In 1933 at least 12 ecclesial groups were active in the United States and Canada. Although they all professed the same religion and sacred life, these churches were in fact completely isolated from each other. In a multi-confessional environment, where the Orthodox were a minority, the need for administrative unity of Orthodoxy on this continent was obvious in order to coordinate joint missionary work.

These mentioned prerequisites compelled the representatives of various Orthodox jurisdictions to start looking for ways to consolidate Orthodoxy in North America. This led to the establishment of close contacts and cooperation.

The American church historian Thomas Fitzgerald identified several areas in which cooperation of Orthodox Christians in North America has been proposed:

1) Proposal for cooperation in the field of church education.

2) Proposal for the establishment of bishops' council as a joint coordinating inter-Orthodox body.

3) Proposal to issue a joint Pan-Orthodox publication.

Despite the vectorial support by the First Hierarchs of various churches in the diaspora, such a body was establiched in 1943. It consisted of four Local Churches, led by the archbishops of the American continent. Archbishop Athenagoras was presented from the Greek Orthodox Archdiocese, Metropolitan Anthony (Bashir) - from Antioch, Metropolitan Benjamin (Fedchenkov) - from the Russian patriarchal parishes, and from the Serbian parishes Bishop Dionysius was represented. Ukrainians, such as Bishop Orest (Chornok), who represented the CarpathianRuthenian diocese, and Bishop Bohdan (Shpilka), also took part in the working meetings of the body. However, this corporation ceased to exist in 1945. Thus, the organization existed for only two years, but during this period several important working meetings took place, which determined the further vector of development of interfaith interaction in North America. It was on the model of the "Conference of Orthodox Bishops" that a similar corporation of the Permanent Conference of Orthodox Bishops was formed in 1960, called SCOBA (Standing Conference of the Orthodox Bishops in America) [9, p. 62].

One of the key tasks of the organization was to discuss and resolve related church issues, strengthen pan-Orthodox unity in the diaspora and coordinate joint projects [12]. The newly formed joint body consisted of separate dioceses, which were under the jurisdiction of the Ecumenical Patriarchate. That is, in fact, Constantinople, which was divided into separate religious organizations, was seeking to unite its own dioceses under a single omophorion in America. Thus, the founders of the conference were the Albanian Diocese, the Greek Archdiocese, the CarpathianRuthenian Diocese, and the Ukrainian Orthodox Church of America. It also included UAOC in exile, which was headed by Archbishop Palladium, The Romanian Diocese, the Bulgarian Diocese, the Serbian Diocese, the Orthodox Archdiocese of Antioch, the "Metropolitan District" and the Exarchate of North and South America, which was under the omophorion of the Moscow Patriarch. Thus, most of the recognized Local Churches represented on the American continent became part of the new coordinating episcopal body [9, p. 62].

However, a number of large jurisdictions found themselves outside the organization, as they were considered "non-canonical" by other members of the conference. The criteria for determining "canonicity" used by the founders of SCOBA are unclear. If such a criterion is belonging to a certain patriarchate, then it seems illogical the participation in a conference of independent church groups: Bulgarian Diocese and UAOC in exile, which, moreover, were not very numerous organizations. At the same time, SCOBA did not accept such numerous churches as the ROCA, the UOC in the United States, the Albanian Diocese, the Syrian Archdiocese of Toledo, and the 
independent Romanian Diocese. Summing up, we note that the "Permanent Conference of Orthodox Bishops of America" did not fulfill its fundamental task - the unification of all Orthodoxy in North America due to the conditional and rather peculiar division of churches into "canonical" and "non-canonical". The desire to coordinate joint actions and potential unification did not bring the desired results. Prolonged preparations for the establishment of a joint inter-Orthodox body, as well as its activity itself, were not effective. The Greek Archbishop Athenagoras again proposed to create a joint journal $[9$, p. 58]. A common press organ in North America was intended to bring together representatives of various jurisdictions who considered themselves to be co-religionists.

The first Pan-Orthodox Congress in the 20th century was convened by Ecumenical Patriarch Meletius IV (Metaxakis) in 1923. Already at the beginning of the last century, the hierarchs were speaking of the need to convene an immediate Great Council, which should resolve a significant number of problems. More than a thousand years have passed since the Seventh Ecumenical Council (787), during which the Church has faced many questions. Among many others, the issues of the administrative structure of the Ecumenical Church are particularly acute, i.e. it was necessary to regulate the formation of a new autocephaly. There is no arrangementor procedure for its proclamation. And also at the beginning of the 20th century there is a new phenomenon of the Orthodox diaspora, the settlement of which required the participation of all Local churches in the Council [8, p. 35]. Ecumenical Hierarch Meletius IV, who was known for his innovation approach, initiated the Pan-Orthodox Meeting. Only a part of the universal church took part in that congress. This gave grounds for criticizing the decisions of the meeting as illegitimate, because it did not represent the opinion of the entire church [5, p. 47].

Among the bold decisions of the 1923 meeting was the idea of holding a Great Cathedral of the Eastern Orthodox Church. Active preparations for the Pan-Orthodox Council began in the 1960s. In this context, a number of meetings were held and several inter-Orthodox theological commissions were organized. Finally, the Council was repeatedly postponed until 2016. One of the most controversial issues were the problems of the proclamation of autocephaly and the leadership of the Orthodox diaspora. As a result, the preparatory process lasted for several decades and continues to this day.

The First Pan-Orthodox meeting took place on the Rhodes island in 1961. The Second meeting took place in 1963, and the Trird - in 1964. Once again, the participants of the meetings expressed a desire to jointly solve the problems of the Ecumenical scale, one of the main of them is the problem of the diaspora.

And the pre-council Pan-Orthodox meeting in Chambésy (1976) determined a catalog of topics for decision at the council. The issue of the Orthodox diaspora was among them [6, p. 5-6]. The issue of the Orthodox diaspora was directly discussed in Chambésy, Switzerland, on November 713, 1993, during a meeting of the Inter-Orthodox Preparatory Commission. In his final report, the Metropolitan of Switzerland, Damaskinos (Papandreou), highlighted the Orthodox community's vision of ways to overcome the existing problems regarding the diaspora. The most important achievement of the Conference should be considered the decision to create episcopal assemblies in each of the regions where the Orthodox diaspora is located. This will help solve problems at the regional level, not the general level. In addition, when making a general decision on the diaspora at the future Great Council, each of these episcopal assemblies must have its own recommendation for the specific future actions. Again, there were some discussions. Misunderstandings have arisen over the question of the leader of such meetings. The Ecumenical Patriarchate was insising on a "diptych list," that is, the leader should be the bishop whose church has the highest place in the diptych. Representatives of other Local Churches believed that the first hierarch of such meetings should be elected [1].

Thus, the holding of Pan-Orthodox conferences contributed to the formation of a compromise point of view of the Orthodox churches in relation to the issue of diaspora management. Finally, a preliminary mechanism for normalizing relations between different parts of the diaspora has been developed. 
As for the countries of Western Europe, they have lagged far behind the American continent in their movement towards the consolidation of various diaspora jurisdictions. The countries of North America showed an example of the unification of administratively fragmented church entities into a single powerful Orthodox organization, for the sake of witnessing the faith in front of the heterodox world. The first episcopal conferences and a number of gatherings laid a solid foundation for further fruitful cooperation in the direction of solving the ecclesiological problem of equipping diaspora churches. The visits of the first hierarchs of the most powerful Local Churches to the American continent became an obvious sign of the movement towards rapprochement between the churches. In particular, the Ecumenical Patriarch visited the United States in 1991 [11].

The end of the 20th century showed a change in priorities in the activities of the Orthodox diaspora in North America. Representatives of various Orthodox jurisdictions on this continent have taken a number of steps to emphasize the real unity of the Orthodox world. Still realizing its national origin and respecting its roots, the Orthodox diaspora in the 1990s was strikingly different from the diaspora in the first half of the 20th century. [4].

However, more than a century has passed since the beginning of resettlement. Today the question arises: can emigrants no longer in the first generation still be considered a "diaspora"? Therefore, the church must develop new approaches to solving this problem. "Lands of the barbarians", which are mentioned in the 28th canon of the Fourth Ecumenical Council [3, p. 63], today should not be compared with the Orthodox diaspora in America and Western Europe. It is necessary to analyze the current situation through the prism of general Episcopal meetings. In fact, "diaspora", in the sense of migrants to a foreign land, has long been outdated. These are people who have long been assimilated in the conditions of their new country of residence. However, they want to preserve the historical faith - Orthodoxy. Therefore, it is necessary to offer options for a canonical way out of the situation.

The situation has been changing since the middle of the 20th century. The new lands were no longer extraneous to the settlers. The first emigrants have already given birth to children and grandchildren in the conditions of the new Motherland. The question of the general church organization arose at the global level. The problem of recognition by Local Churches arose in other ethno-confessional formations. Some dioceses were re-subordinated to already recognized church units. Most often, the churches have been moved off under the omophorion of Ecumenical Primate [10].

An important meeting, which started a new page in the history of interfaith interaction, took place on November 30, 1994 in the township of Ligonier, Pennsylvania. 29 bishops from different jurisdictions of the American continent gathered. The final document of the meeting "A Word about the Church in North America" shows a change in worldview paradigm. The bishops have offered to abandon the term "diaspora" to describe American churches. It is incorrect from the point of view of Orthodox ecclesiology. The diaspora means something temporary, inferior. And in the USA and Canada, full-fledged churches have been functioning and steadily developing for a long time [11].

However, the initiatives of local bishops in America were rejected by the mother churches. In particular, the decision of the meeting in Ligoniere was refused to be recognized by Ecumenical Patriarch. It is he who most painfully reacts to any jurisdictional changes on the American continent. Most of the congregations and parishes in the USA and Canada are under his jurisdiction. Interestingly, but more than a dozen individual dioceses and "Churches of the Diaspora" in the same country belong to the same patriarchy, but do not form a homogeneous church.

The Great Council in Crete in 2016 did not radically change the situation with the diaspora. A separate document "Orthodox Diaspora" was issued in the final materials of the Council, however, it did not offer anything new compared to the pre-council meetings in Chambésy and others. The Council stated the traditional self-evident things. All Local Churches have the will to solve the problem of the Orthodox diaspora, since everyone agrees that the current situation is not canonical. [2, p. 61-70]. 
The participants of the meeting testified to the impossibility of immediate transition to the canonical structure of the church diaspora (mainly due to the unwillingness of churches to lose income from rich countries). Everyone understands that there should be a single bishop in a single city, and a single first hierarch in a single country. To do this, one church needs to be created, for example, the Orthodox Church in America or Canada. However, due to the financial component, which was not officially discussed at the Council, canonical acrivia (strict application of the rules) is currently impossible. The result of the document is the delineation of the diaspora churches into regions. Their boundaries are clearly defined. In general, the following XIII sectors were formed: Canada; USA; Latin America; Australia, New Zealand and Oceania; Great Britain and Ireland; France; Belgium, the Netherlands and Luxembourg; Austria; Italy and Malta; Switzerland and Liechtenstein; Germany; Scandinavian countries (except Finland); Spain and Portugal. "Episcopal Assemblies" will be established in each of the regions, a body that already have some experience of existence, in particular in America. The first bishop in the diptych, who is represented in the region, will lead such meetings. In most regions, it will be a hierarch from the Patriarchate of Constantinople. Such assemblies will include all incumbent bishops of a particular region who are canonically mutually recognized. Therefore, for example, the American Orthodox Church, which has significant experience of living and functioning in the diaspora, will not be part of such assemblies.

Summarizing the above, we can state that the desire to consolidate the Orthodox diaspora was expressed by the clergy and laity of the emigrant churches. At the same time, consensus was not reached due to the opposition of the chiarchal churches, which especially valued the connection with the foreign flock, mainly for financial reasons. In addition, the existence of ethnic jurisdictions is a guarantee of preserving of culture and traditions while staying outside the Homeland. Therefore, a large part of the diaspora cannot agree to sever ties with the Church of the Motherland.

Conclusions and prospects for further research. The problem of the Orthodox diaspora became acute in the 19th and 20th centuries, when active migration processes were unfolding in Europe and North America. Church canons do not give a clear explanation of the administrative status of the diaspora. Different interpretations of the canons led to the creation of a unique ecclesiological model, according to which the representations of many Local Churches appeared simultaneously in the same country. A situation has arisen when there are several Orthodox bishops of different churches in the same territory, which is a gross violation of the traditions and canons of the Orthodox Church. Orthodox leaders have been looking for ways to solve this problem for the past century, however, they have never managed to find a compromise, and the issue of settling the status of the Orthodox diaspora remains open. The rivalry between the Local Churches over the subordination of the diaspora is a "wound" on the body of the Orthodox Church. Solving this problem is one of the priorities for the Orthodox community. The Great Council in Crete did not give a clear answer, despite considerable attention to this issue. The whole diaspora was proposed to be divided into XIII regions, in each of which the "Episcopal Assembly" will operate, which is more of an advisory rather than an administrative body.

Based on the analysis of the historical formation of the diaspora churches, it can be argued that the Orthodox diaspora has become an alternative form of organization of the church structure. This form of organization of church life was contrary to the traditions of the church, however, it was justified by the special historical conditions that prevailed in the 20th century. Local Orthodox churches, in conditions of political instability, constant military conflicts and revolutionary changes, could not coordinate joint activities in a timely manner. Therefore, they were obliged to respond to the requests of the flock and create a church structure in the diaspora independently of each other. However, such a situation with the diaspora is possible as a temporary one, when migrants have just settled in a new place, and are only planning their future life, including the church one. The first emigrants came to America more than 200 years ago, therefore, the hierarchs of Local Churches should discard their own ambitions and financial needs, and move towards a canonical solution to the problem of the diaspora by uniting into one Local Church. 


\section{Список використаних джерел та літератури}

1. Дамаскин (Папандреу). (1993). Доклад на заседании Межправославной Подготовительной Комиссии, Шамбези. [Электронныги ресурс]. Режим доступа: http://www.orthodox researchinstitute.org. (дата звернення: 26.09.2020).

2. Документи Святого і Великого Собору Православної Церкви. Крит, 2016. К.: Відкритий Православний Університет Святої Софії Премудрості, ДУХ І ЛІТЕРАТУРА, 2016. 112 с.

3. Книга правил Святых Апостол, Святых Соборов Вселенских и Поместных и Святых Отец. М.: издво святителя Льва, Папы Римского, 2010. 447 с.

4. Пантелеймон (Родопулос). Територіальні юрисдикції відповідно до православного канонічного права. Феномен етнофілетизму у наш час. [Електронний ресурс]. Режим доступу: http://vira.in.ua/texts/rodopoulos_jurisdictions_ua.htm. (дата звернення: 15.10.2020).

5. Скурат К. Константинопольский патриархат и проблемы диаспоры. Журнал Московской патриархии. 1989. № 10. С. 45-49.

6. Справка о Всеправославных совещаниях и перечень тем для всеправославного обсуждения. Журнал Московской Патриархии. 1977. № 1. С. 4-8.

7. Точки домовлення між УПЦ в Канаді і Вселенською Константинопольською патріархією. Articles of Agreement between UOC in Canada and Ecumenical patriarchate of Consantinople. Winnipeg: Consistory of the Ukrainian Orthodox Church of Canada; «Ecclesia» Publishing Corporation, 2000. 59 p.

8. Троицкий С. О границах распростанения права власти Константинопольськой патриархии на «діаспору». Журнал Московской патриархии. 1947. № 11. С. 34-45.

9. Fitz Gerald T. The Orthodox Church. - Westport: Greenwood Press, 1995. 335 p.

10. Krindatch A. The Orthodox (Eastern Christian) Churches in the USA at the Beginning of a New Millennium. Research on Orthodox Religious Groups in the United States. Retrieved from: http://hirr.hartsem.edu/research/orthodoxpaper.html (дата звернення: 15.10.2020).

11. Stokoe M., Kishkovsky M. Orthodox Christians in North America, 1794-1994. Syosset, NY., 1995. 145 p. Retrieved from: http://www.oca.org/ MVorthchristian snamerica.asp? SID=1\&Chap=INTRO (дата звернення: 15.10.2020).

12. The Constitution of the Standing Conference of Canonical Orthodox Bishops in the Americas. Retrieved from: http://www.scoba.us/ resources/constitution.html (дата звернення: 15.10.2020).

\section{References (translated \& transliterated)}

1. Damaskin (Papandreu). (1993). Pravoslavnaya diaspora. Doklad na zasedanii Mezhpravoslavnoy Podgotovitel'noy Komissii. Retrieved from: http://www.orthodox researchinstitute.org. (in Russian).

2. Dokumenty Svjatogo i Velykogo Soboru Pravoslavnoi' Cerkvy. Kryt, 2016. (2016). K.: Vidkrytyj Pravoslavnyj Universytet Svjatoi' Sofii' Premudrosti, DUH I LITERATURA (in Ukrainian).

3. Kniga pravil Svyatykh Apostol, Svyatykh Soborov Vselenskikh i Pomestnykh i Svyatykh Otets. (2010). M.: izd-vo svyatitelya L'va, Papy Rimskogo (in Russian).

4. Panteleymon (Rodopulos). Tery`torial'ni yury`sdy`kciyi vidpovidno do pravoslavnogo kanonichnogo prava. Fenomen etnofilety zmu $u$ nash chas. Retrieved from: http://vira.in.ua/texts/rodopoulos_jurisdictions_ua.htm (in Ukrainian).

5. Skurat, K. (1989). Konstantinopol'skiy patriarkhat i problemy diaspory. Zhurnal Moskovskoy patriarkhii [Journal of the Moscow Patriarchate], 10, 45-49 (in Russian).

6. Spravka o Vsepravoslavnuh soveshhanyjah y perechen' tem dlja vsepravoslavnogo obsuzhdenyja. (1977). Zhurnal Moskovskoj Patryarhyy, 1, 4-8 (in Russian).

7. Articles of Agreement between UOC in Canada and Ecumenical patriarchate of Consantinople. (2000). Winnipeg: Consistory of the Ukrainian Orthodox Church of Canada; «Ecclesia» Publishing Corporation (in Ukrainian).

8. Troitskiy, S. (1947). O granitsakh rasprostaneniya prava vlasti Konstantinopol's'koy patriarkhii na «diasporu». Zhurnal Moskovskoy patriarkhii, 11, 34-45 (in Russian).

9. Fitz Gerald, T. (1995). The Orthodox Church. Westport: Greenwood Press (in English).

10. Krindatch, A. The Orthodox (Eastern Christian) Churches in the USA at the Beginning of a New Millennium. Research on Orthodox Religious Groups in the United States. Retrieved from: http:/hirr.hartsem.edu/research/orthodoxpaper.html (in English).

11. Stokoe, M., Kishkovsky, M. (1995). Orthodox Christians in North America, 1794-1994. Syosset, NY. Retrieved from: http://www.oca.org/ MVorthchristian snamerica.asp? SID=1\&Chap=INTRO (in English).

12. The Constitution of the Standing Conference of Canonical Orthodox Bishops in the Americas. Retrieved from: http://www.scoba.us/ resources/constitution.html (in English).

Статтю отримано $20.10 .2020 \mathrm{p}$.

Прийнято до друку 03.11.2020 p. 